\title{
Land Surface Models Evaluation for Two Different Land-Cover Types: Cropland and Forest
}

\author{
Daeun Kim ${ }^{1}$, Seokkoo Kang ${ }^{1}$, and Minha Choi ${ }^{2, *}$ \\ ${ }^{I}$ Department of Civil and Environmental Engineering, Hanyang University, Seoul, Republic of Korea \\ ${ }^{2}$ Water Resources and Remote Sensing Laboratory, Department of Water Resources, Graduate School of Water Resources, \\ Sungkyunkwan University, Suwon, Republic of Korea
}

Received 3 March 2015, revised 13 October 2015, accepted 14 September 2015

\begin{abstract}
Land Surface Model (LSM) is an important tool used to understand the complicated hydro-meteorological flux interaction systems between the land surface and atmosphere in hydrological cycles. Over the past few decades, LSMs have further developed to more accurately estimate weather and climate hydrological processes. Common Land Model (CLM) and Noah Land Surface Model (Noah LSM) are used in this paper to estimate the hydro-meteorological fluxes for model applicability assessment at two different flux tower sites in Korea during the summer monsoon season. The estimated fluxes such as net radiation $\left(R_{N}\right)$, sensible heat flux $(H)$, latent heat flux $(L E)$, ground heat flux $(G)$, and soil temperature $\left(T_{s}\right)$ were compared with the observed data from flux towers. The simulated $\mathrm{R}_{\mathrm{N}}$ from both models corresponded well with the in situ data. The rootmean-square error (RMSE) values were $39-44 \mathrm{~W} \mathrm{~m}^{-2}$ for the CLM and $45-50 \mathrm{~W} \mathrm{~m}^{-2}$ for the Noah LSM while the H and LE showed relatively larger discrepancies with each observation. The estimated $\mathrm{T}_{\mathrm{s}}$ from the CLM corresponded comparatively well with the observed soil temperature. The CLM estimations generally showed better statistical results than those from the Noah LSM, even though the estimated hydro-meteorological fluxes from both models corresponded reasonably with the observations. A sensitivity test indicated that differences according to different locations between the estimations from models and observations were caused by field conditions including the land-cover type and soil texture. In addition the estimated $\mathrm{R}_{\mathrm{N}}$, $\mathrm{H}, \mathrm{LE}$, and $\mathrm{G}$ were more sensitive than the estimated $\mathrm{T}_{\mathrm{s}}$ in both models.
\end{abstract}

Key words: Water and energy fluxes, Common Land Model, Noah Land Surface Model

Citation: Kim, D., S. Kang, and M. Choi, 2016: Land Surface Models evaluation for two different land-cover types: Cropland and forest. Terr. Atmos. Ocean. Sci., 27, 153-167, doi: 10.3319/TAO.2015.09.14.02(Hy)

\section{INTRODUCTION}

Land surface fluxes produced by Land Surface Models (LSMs) represent the physical processes that adjust the transfer of water and energy into the atmosphere after precipitation and solar radiation reach the land surface (Zeng et al. 2002; Rodell et al. 2005). Recently, bucket-type LSMs have been further developed for the purpose of designing an effective tool to estimate the hydrological processes and components of weather and climate systems (Bastidas et al. 2003). Over the past few decades the focus of LSMs research studies has been land-surface developments and parameterizations (Avissar and Pielke 1989; Li and Avissar 1994; Oleson et al. 1997; Liang and Guo 2003; Kahan et al.

\footnotetext{
* Corresponding author

E-mail:mhchoi@skku.edu
}

2006; Han et al. 2008; Patil et al. 2011). A number of experiments have been conducted to develop and evaluate LSMs with the goal of facilitating their advancement (Hogue et al. 2005).

The Common Land Model (CLM) and Noah Land Surface Model (Noah LSM) have been developed so that the Global Energy and Water Experiment (GEWEX) can be applied to forecast climate components along with other models such as the Variable Infiltration Capacity model (VIC; Liang et al. 1994; Peters-Lidard et al. 1997) and the National Aeronautic and Space Administration (NASA)'s Mosaic LSM (De Haan et al. 2007). The CLM, a Soil-VegetationAtmospheric Transfers (SVAT) model, was developed by the National Center for Atmospheric Research (NCAR) and is recognized as one of the most advanced NCAR LSM types 
for improving land-surface biophysical processes (Bonan et al. 2002). Niu and Yang (2006) showed that the CLM is advantageous for terrestrial water storage simulations for soil moisture and snow water compared with Gravity Recovery and Climate Experiment (GRACE) data. Stöckli et al. (2008) modified several CLM calibration schemes at a number of fields including north boreal, Mediterranean, and tropical regions. Choi et al. (2010) acquired reasonable results for energy and water fluxes using CLM with in situ flux data from the Korea Flux Network (KoFlux) during the growing season at a farmland area. Li et al. (2012) modified the soil thermal conductivity in the CLM to improve simulated fluxes on bare soil in the Loess Plateau of Northwestern China. Yang et al. (2009) employed LSMs including the CLM, Noah LSM, and Simple Biosphere Model 2 (SiB2) in the Tibetan Plateau to estimate soil water content.

The Noah LSM was first developed in 1993 through multi-institutional cooperation (Mahrt and Ek 1984; Mahrt and Pan 1984; Pan and Mahrt 1987; Chen et al. 1996, 1997; Schaake et al. 1996; Koren et al. 1999; Ek et al. 2003; Niu et al. 2011) under sponsorship from the GEWEX, GEWEX Continental-Scale International Project (GCIP), and GEWEX Americas Prediction Project (GAPP; Mitchell 2005). The Noah LSM is a stand-alone model that can be implemented in a coupled or uncoupled mode and is widely used for accurate water and energy flux simulations (Kato et al. 2007). Similar to a number of CLM applications, the land-surface parameters were also simulated using the Noah LSM under a variety of field conditions. Van der Velde et al. (2009) simulated surface heat fluxes and temperature states in soil profiles and identified the various simulation effects to adjust the soil and vegetation parameters using the Noah LSM in the Tibetan plateau. Patil et al. (2011) employed the Noah LSM for land-surface variables under tropical conditions in Gujarat, India, whereby the simulated skin temperature and net radiation were in good agreement with observations under a dry condition. However, the simulated soil temperature at different depths was particularly discordant under a wet condition. The Oregon State University (OSU) LSM and the Noah LSM were used by De Haan et al. (2007) to simulate meteorological variables. Compared with the OSU LSM, the Noah LSM produced more reasonable results regarding the simulated temperature, precipitation variability and precipitation climatology. Radell and Rowe (2008) simulated land-surface fluxes using the Noah LSM at a sand hill and in wet and dry valleys in the Nebraska Sand Hills. Their results showed sound agreement between the Noah LSM and the in situ data for the mean diurnal and annual energy fluxes. In most cases, the root-mean-square error (RMSE) was $20-25 \%$. Hogue et al. (2005) identified that the Noah LSM accurately generated energy budget components when compared with in situ data at two semiarid sites in southern Arizona.

Over the previous decade primary studies were carried out to estimate hydro-meteorological variables using LSMs in different countries. However, a dearth of research exists regarding the main hydrological cycle components from a standalone LSM simulation in Korea. In this study we assessed the applicability of the CLM and Noah LSM in Korea. The hydro-meteorological fluxes included net radiation $\left(\mathrm{R}_{\mathrm{N}}\right)$, sensible heat flux $(\mathrm{H})$, latent heat flux (LE), ground heat flux $(\mathrm{G})$, and soil temperature $\left(\mathrm{T}_{\mathrm{s}}\right)$. The corresponding flux estimates from the two LSMs were evaluated through a comparison between the estimated fluxes and observations observed from two different eddy-covariance flux towers during the early summer of 2012. In the following section descriptions of the model are presented along with an overview of the CLM and Noah LSM. Section 3 describes the study sites and in situ data. The temporal variations of the simulated fluxes and observations are presented and discussed in section 4, along with the sensitivity analyses for both models. Our conclusions are presented in section 5 .

\section{MODEL DESCRIPTIONS}

\subsection{Land Surface Models (LSMs)}

The CLM is a state-of-the-art model developed by various groups from multi-institutional projects (Whitfield et al. 2006; Meng et al. 2009). The CLM is based on a Community Land Model (Bonan et al. 2002) that was developed from a combination of LSMs, the Biosphere-Atmosphere Transfer Scheme (BATS), and an LSM from the Chinese Academy of Sciences Institute of Atmospheric Physics (Dai et al. 2003). The model can measure land-surface fluxes and interpret the interaction between the land surface and atmosphere (Dai et al. 2003). The CLM process was developed to employ a variety of parameterization schemes from other LSMs that had been improved (Huang et al. 2008; Meng et al. 2009; Li et al. 2012).

The CLM can calculate runoff and infiltration that has been detected by the TOPography based hydrological MODEL (TOPMODEL; Beven and Kirkby 1979). The model uses 10 soil layers for soil moisture and temperature estimations and it employs the MOSAIC method for grid-scale calculations. The CLM was derived from the vegetation classification from the International GeosphereBiosphere Programme (IGBP), and grid-classified representative land-surface boundary conditions are used to obtain more accurate results (Lawrence and Chase 2007). The CLM calculates hydro-meteorological variables such as heat fluxes, soil moisture, runoff, and air temperature. The basic information includes longitude/latitude, height of forcing data measurement, soil texture and color, porosity, leaf area index, and IGBP land cover classification to execute the CLM. The initial dataset includes soil moisture, soil temperature, and air temperature obtained from observations for accurate results. The CLM 2.1 version was used in this study to calculate the hydro-meteorological fluxes. 
The Noah LSM was developed by the National Centers for Environmental Prediction (NCEP), OSU, the Air Force, the Hydrology Research Laboratory at the National Weather Service under the sponsorship of the National Oceanic and Atmospheric Administration (NOAA) Office of Global Programs (OGP), and the regional Eta model and its Eta Assimilation System (EDAS). The Noah LSM operates based on the energy and water balance equations (Sridhar et al. 2003). The model can be simulated independently or in combination with other models such as the Weather Research and Forecasting model (WRF; Kato et al. 2007). The model contains four soil layers measuring 10, 20, 60, and $100 \mathrm{~cm}$, and its root zone depth can be changed spatially according to the vegetation class (De Haan et al. 2007). The model can further be implemented for 13 vegetation covers and 9 soil types (Hogue et al. 2005). The Noah LSM considers the soil surface resistance according to the relationship between the evaporation efficiency and soil water content (Yang et al. 2009). The Noah LSM also required initial data and parameterization to execute the model. The basic information includes site location, number of soil layers, height of the forcing measurement, soil type, vegetation type, slope type, monthly albedo, and monthly green vegetation fraction fed according to the environmental condition at study sites. In addition, the initial skin temperature and canopy water content were modified for initial state variables. Those data were obtained from flux tower measurement at study sites. Noah LSM version 2.7.1 was used in this study.

These LSMs have similar basic structure for reproducing the hydro-meteorological cycle. The two models represent realistic land processes and understanding the feedback and interactions together. The major difference between the two models is that the CLM has relatively fewer user defined parameters than other LSMs (Dai et al. 2003). In addition, the number of soil layers and soil texture and land cover types classification varies for the flux calculation.

\subsection{Basic Equations of LSM}

The CLM and Noah LSM are based on the water-massbalance equation [Eq. (1)] and energy-conservation equation [Eq. (2); Dai et al. 2003], as follows:

$$
\begin{aligned}
\frac{\partial}{\partial t} \int_{\Delta V} \rho_{k} \theta_{k} d V=- & \int_{S} U_{k} \cdot d s+\sum_{k^{\prime}} \int_{\Delta V} M_{k^{\prime} k}\left(1-\delta_{k^{\prime} k}\right) d V \\
& +\int_{\Delta V} S_{k} d V \\
\frac{\partial}{\partial t} \sum_{k=i, l, v, d} \int_{\Delta V} \rho_{k} \theta_{k} h_{k} d V=- & \sum_{k=i, l, v} \int_{S} U_{k} h_{k} \cdot d S \\
& +\int_{S} \lambda \nabla T \cdot d S+\int_{\Delta V} R d V
\end{aligned}
$$

In Eq. (1), $V$ is the control volume $\left(\mathrm{m}^{-3}\right), \rho_{k}$ is the intrinsic density of constituent $k\left(\mathrm{~kg} \mathrm{~m}^{-3}\right), \theta_{k}$ is the partial volume of constituent $k\left(\mathrm{~m}^{3} \mathrm{~m}^{-3}\right), U_{k}$ is the mass flux $\left(\mathrm{kg} \mathrm{m}^{-2} \mathrm{~s}^{-1}\right), M_{k^{\prime} k}$ is the phase change from phase to phase $\left(\mathrm{kg} \mathrm{m}^{-3} \mathrm{~s}^{-1}\right), M_{k^{\prime} k}$ is the Kronecker delta, and $S_{k}$ is a source or sink term. In Eq. (2), $T$ is temperature (K), $\lambda$ is the thermal conductivity of the medium $\left(\mathrm{W} \mathrm{m} \mathrm{m}^{-1} \mathrm{~K}^{-1}\right)$, and $R$ is radiation flux $\left(\mathrm{W} \mathrm{m}^{-2}\right)$.

\section{STUDY SITES, IN SITU DATA, AND INITIAL PARAMETERIZATION}

We executed the two models at the Cheongmicheon (CMC) and Seolmacheon (SMC) sites (Fig. 1). The two models produced hydro-meteorological fluxes such as $\mathrm{R}_{\mathrm{N}}$, $\mathrm{H}, \mathrm{LE}, \mathrm{G}$, and $\mathrm{T}_{\mathrm{s}}$. These variables were validated at the CMC and SMC sites using comparison with the in situ data from flux towers.

\subsection{Cheongmicheon Site (CMC)}

The CMC site is located on the northeastern side of South Korea. The site geographical information is indicated in Table 1. The CMC watershed area is $595.70 \mathrm{~km}^{2}$ with a slope of $17.01 \%$, and the flow channel length is $60.8 \mathrm{~km}$ (Yi et al. 2010). The flux tower was located at $37^{\circ} 9^{\prime} 35^{\prime}$ ' $\mathrm{N}$, $127^{\circ} 39^{\prime} 10^{\prime}$ 'E to record the fluxes at $30 \mathrm{~min}$ intervals. The flat-terrain site comprises farmland between a river and mountains and the soil varies from sandy loam to loam. The specific vegetation ratio is $48.5 \%$ mountains, $43.1 \%$ farmland, and $8.4 \%$ other vegetation types. The annual mean air temperature is $11.5^{\circ} \mathrm{C}$ and the annual mean precipitation is $1107 \mathrm{~mm}$, with the maximum precipitation occurring during the summer rainy season.

\subsection{Seolmacheon Site (SMC)}

The SMC site is located on the northern side of South Korea. The SMC watershed area is $8.51 \mathrm{~km}^{2}$ with a slope of $36.96 \%$, representing a typical steep-slope mountain channel. The channel length is $5.50 \mathrm{~km}$ with a slope of $3.10 \%$ (Jang et al. 2007). The SMC is comprised of complex terrain with needle- and broad-leaf tree vegetation types. The soil varies from sandy loam to loam. The latitude and longitude of the flux tower are $37^{\circ} 56^{\prime} 18^{\prime}$ ' $\mathrm{N}$ and $126^{\circ} 57^{\prime} 12^{\prime}$ ' $\mathrm{E}$, respectively. The annual mean air temperature and annual mean precipitation are $11.5^{\circ} \mathrm{C}$ and $1332 \mathrm{~mm}$, respectively.

\subsection{In Situ Data}

The in situ data from the CMC and SMC flux towers were measured at the Hydrological Survey Center (HSC) in Korea. The meteorological variables that were observed using eddy-covariance techniques were provided at each site. These techniques are generally used to measure energy fluxes. An open-path measurement system was employed at the study sites and the flux-measurement instruments are 
described in Table 2. The data were implemented with quality control based on micro-meteorological theories and a statistical test (e.g., quality flagging, the control of ranges and spikes, correction of coordinate rotation) (Kwon et al. 2007, 2009) for instrumental measurement errors supplementation and data-accuracy procurement. The quality control could

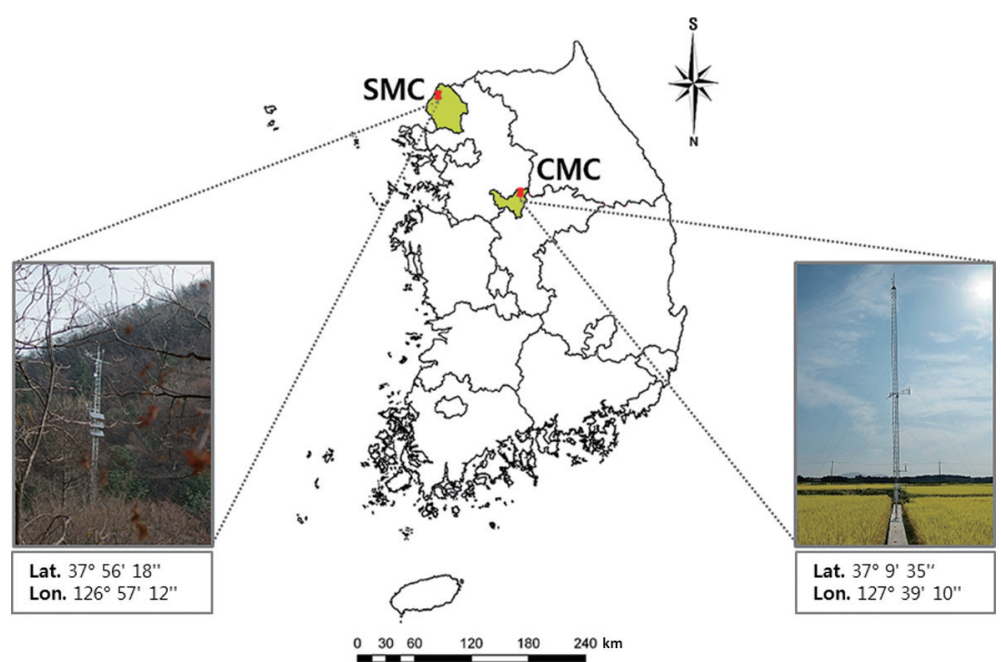

Fig. 1. Study sites with flux towers. (Color online only)

Table 1 . The characteristics of the study sites.

\begin{tabular}{|c|c|c|c|c|c|c|c|}
\hline Sites & Latitude/Longitude & Terrain types & Vegetation types & Soil types & $\begin{array}{l}\text { Mean annual air } \\
\text { temperature }\left({ }^{\circ} \mathbf{C}\right)\end{array}$ & $\begin{array}{c}\text { Mean annual } \\
\text { precipitation } \\
(\mathbf{m m})\end{array}$ & Study period \\
\hline CMC & $37^{\circ} 9^{\prime} 35^{\prime \prime} / 127^{\circ} 39^{\prime} 10^{\prime \prime}$ & Flat & Cropland & Sandy loam to Loam & 11.5 & 1107 & \multirow{2}{*}{$\begin{array}{c}152-173 \\
(\mathrm{DOY}) \text { in } 2012\end{array}$} \\
\hline SMC & $37^{\circ} 56^{\prime} 18^{\prime \prime} / 126^{\circ} 57^{\prime} 12^{\prime \prime}$ & Complex Terrain & Mixed Forest & Loamy sand to Loam & 11.5 & 1332 & \\
\hline
\end{tabular}

Table 2. Flux measurement instruments at the study sites.

\begin{tabular}{|c|c|c|}
\hline Study sites & Variables & Instruments \\
\hline \multirow{8}{*}{ CMC } & Wind speed & RM81000 3D Sonic Anemometer (RMYoung, USA) \\
\hline & Air temperature & RM81000 3D Sonic Anemometer (RMYoung, USA) \\
\hline & Water vapor & KH20 Hygrometer (Campbell Sci., USA) \\
\hline & Barometric pressure & Vaisala Weather Transmitter (WXT510, Vaisala, Finland) \\
\hline & Precipitation & Vaisala Weather Transmitter (WXT510, Vaisala, Finland) \\
\hline & Soil temperature & TCAVs (Campbell Sci., USA) \\
\hline & Net radiation & Net Radiometer (CRN2, Kipp and Zonen, Netherlands) \\
\hline & Soil heat flux & Heat Flux plate (HFP01SC, Campbell Sci., Inc., USA) \\
\hline \multirow{8}{*}{ SMC } & Wind speed & 3D sonic anemometer (CSAT3, Campbell Sci., Inc., USA) \\
\hline & Air temperature & 3D sonic anemometer (CSAT3, Campbell Sci., Inc., USA) \\
\hline & Water vapor & Open path (LI-7500, Li-Cor, USA) \\
\hline & Barometric pressure & $\begin{array}{l}\text { Open path (LI-7500, Li-Cor, USA) } \\
\text { AWS (WXT-510, Vaisala, Finland) }\end{array}$ \\
\hline & Precipitation & AWS (WXT-510, Vaisala, Finland) \\
\hline & Soil temperature & Soil thermocouple probe (TCAV, Campbell Sci., Inc., USA) \\
\hline & Net radiation & Net radiometer (CNR1, Kipp and Zonen, Netherlands) \\
\hline & Soil heat flux & Heat Flux plate (HFP01SC, Campbell Sci., Inc., USA) \\
\hline
\end{tabular}


contribute to attaining stable flux data.

\subsection{Initial Parameterization}

The soil and vegetation parameterization are shown in Table 3. The CLM and Noah LSM produced different parameter values due to the distinction between the parameter compositions of both models. Vegetation parameters values such as the leaf area index $\left(\mathrm{m}^{2} \mathrm{~m}^{-2}\right)$ and canopy roughness length $(\mathrm{m})$ were predetermined using a land-cover classification for both models. Table 3 shows the CLM and Noah LSM vegetation and soil parameters given in accordance with the initially chosen land-cover types for each model.
The selected CLM vegetation parameters are cropland (CMC) and mixed forest (SMC), while the cultivations (CMC) and broad- and needle-leaf trees (SMC) are the Noah LSM parameters. The albedo (unit less) of the Noah LSM is a user-defined parameter that is a reference to Brutsaert (1982).

\section{RESULTS AND DISCUSSIONS}

\subsection{Estimated Hydro-Meteorological Fluxes}

Figure 2 shows the time series for the estimated $\mathrm{R}_{\mathrm{N}}$ for both the CLM and Noah LSM models at the CMC and SMC sites. Notably the estimated $R_{N}$ was in sound agreement

Table 3. Initial parameterization of soil and vegetation at the study sites.

\begin{tabular}{|c|c|c|c|c|c|}
\hline Parameters (CLM) & Cropland & Mixed forest & Parameters (Noah LSM) & Cultivations & $\begin{array}{l}\text { Broad-leaf and } \\
\text { needle-leaf trees }\end{array}$ \\
\hline Soil texture & $\begin{array}{l}\text { Sandy Loam to } \\
\text { Loam }\end{array}$ & $\begin{array}{c}\text { Loamy Sand to } \\
\text { Loam }\end{array}$ & Soil texture & $\begin{array}{l}\text { Sandy Loam to } \\
\text { Loam }\end{array}$ & $\begin{array}{c}\text { Loamy Sand to } \\
\text { Loam }\end{array}$ \\
\hline Porosity $\left(\mathrm{m}^{3} \mathrm{~m}^{-3}\right)$ & 0.458 & 0.450 & Porosity $\left(\mathrm{m}^{3} \mathrm{~m}^{-3}\right)$ & 0.404 & 0.468 \\
\hline Leaf area index $\left(\mathrm{m}^{2} \mathrm{~m}^{-2}\right)$ & $0.05-6.00$ & $3.00-6.00$ & Leaf area index $\left(\mathrm{m}^{2} \mathrm{~m}^{-2}\right)$ & $0.00-5.00$ & $0.00-5.00$ \\
\hline Canopy roughness length $(\mathrm{m})$ & 0.06 & 0.80 & Canopy roughness length $(\mathrm{m})$ & 0.075 & 0.800 \\
\hline Saturated hydraulic conductivity $\left(\mathrm{mm} \mathrm{s}^{-1}\right)$ & \multicolumn{2}{|c|}{ Clapp and Hornberger (1978) } & Albedo (Unit less) & 0.15 & 0.20 \\
\hline Stomatal resistance $\left(\mathrm{s} \mathrm{m}^{-1}\right)$ & \multicolumn{2}{|c|}{ Collatz et al. (1991) } & Stomatal resistance $\left(\mathrm{s} \mathrm{m}^{-1}\right)$ & 40 & 125 \\
\hline Thermal conductivity $\left(\mathrm{W} \mathrm{m}^{-1} \mathrm{~K}^{-1}\right)$ & \multicolumn{2}{|c|}{ Farouki (1981) } & Green vegetation fraction (Unitless) & 0.80 & 0.80 \\
\hline
\end{tabular}

(a)

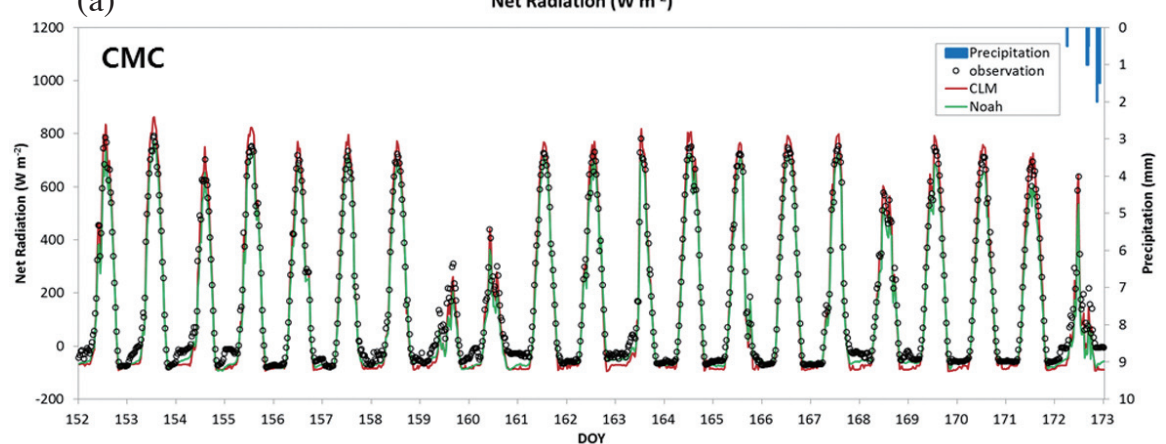

(c)

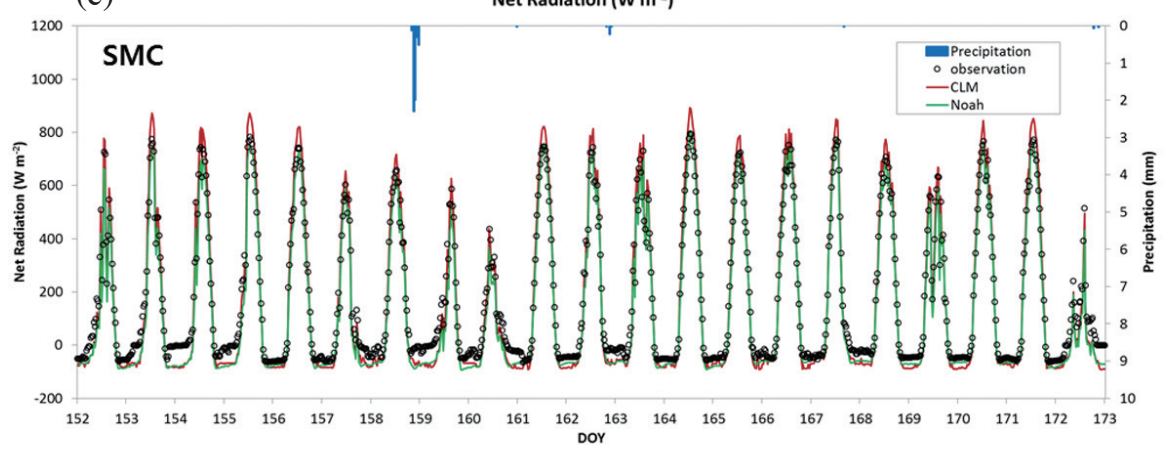

(b)

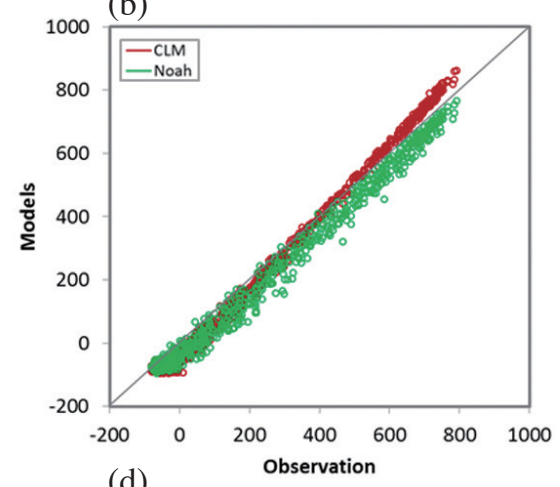

(d)

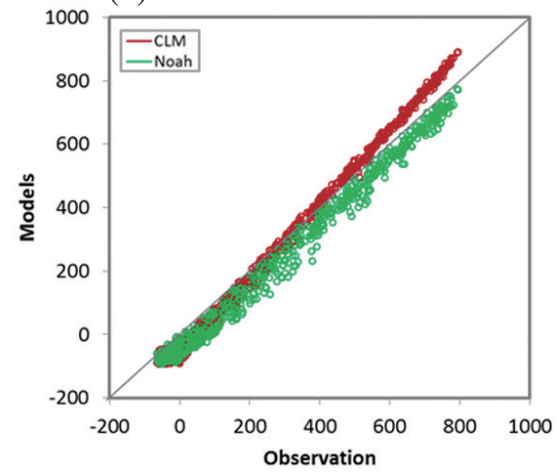

Fig. 2. Time series of observed and simulated net radiations $\left(\mathrm{R}_{\mathrm{N}}\right)$ at (a) CMC and (c) SMC and scatter plots between observed and simulated $\mathrm{R}_{\mathrm{N}}$ at (b) CMC and (d) SMC for 31 May - 21 June 2012. (Color online only) 
with the observed $R_{N}$ at both sites. Figure 2 shows that the estimated $R_{N}$ from the CLM was slightly overestimated by about $50 \mathrm{~W} \mathrm{~m}^{-2}$ in comparison with the observations.

However, the estimated $R_{N}$ from the Noah LSM was underestimated by about $10 \mathrm{~W} \mathrm{~m}^{-2}$ relative to the daytime observations. Although differences exist between the two models, these values are quite small and the night-time low values are distributed around $-70 \mathrm{~W} \mathrm{~m}^{-2}(\mathrm{CMC})$ and $-60 \mathrm{~W} \mathrm{~m}^{-2}$ (SMC). Overall, the ranges varied from $-96-863 \mathrm{~W} \mathrm{~m}^{-2}$ (CLM) and from -96 - $767 \mathrm{~W} \mathrm{~m}^{-2}$ (Noah LSM) at CMC, and from $-91-841 \mathrm{~W} \mathrm{~m}^{-2}$ (CLM) and $-93-774 \mathrm{~W} \mathrm{~m}^{-2}$ (Noah LSM) at SMC. The scatter plots show a nearly straight line between the observations and estimations with coefficient of determination $\left(r^{2}\right)$ values of 0.99 (Figs. $2 b$ and d). The difference between the estimated $R_{N}$ under cropland and mixed-forest conditions is only slight.

Figure 3 presents the time series for the observed and estimated $\mathrm{H}$, whereby the estimated $\mathrm{H}$ shows more discrepancies than the estimated $R_{N}$. In Fig. 3a and Table 4 the estimated $\mathrm{H}$ from the CLM was more accurate in comparison with the estimated $\mathrm{H}$ from the Noah LSM, which was underestimated during most of the study period. The RMSE was $87 \mathrm{~W} \mathrm{~m}^{-2}$ (CLM) and $109 \mathrm{~W} \mathrm{~m}^{-2}$ (Noah LSM) at $\mathrm{CMC}$ and $76 \mathrm{~W} \mathrm{~m}^{-2}$ (CLM) and $151 \mathrm{~W} \mathrm{~m}^{-2}$ (Noah LSM) at SMC, with $\mathrm{r}^{2}$ values of 0.77 (CLM) and 0.59 (Noah LSM) at CMC, and 0.92 (CLM) and 0.90 (Noah LSM) at SMC (Table 4). The precipitation effect appeared to be relatively large for the CLM and it was distinct from the pattern of observations and estimations from the Noah LSM (Fig. 3) even though the estimated $\mathrm{H}$ from the CLM plunged into negative quantities during the precipitation events at both sites. This phenomenon was caused by LE overestimation during rainfall events for energy balance in the CLM (Choi et al. 2010). Overall, the observed H from the CLM showed a decreased pattern (with an increased pattern of LE) during the monsoon period. The Noah LSM could not perfectly reproduce $\mathrm{H}$ during this period.

The estimated LE from the CLM and Noah LSM showed similar trends to those observed for $\mathrm{H}$ (Fig. 4). The $\mathrm{H}$ and LE are major components of determining $\mathrm{R}_{\mathrm{N}}$, so the $\mathrm{H}$ and LE values therefore complemented each other (Stöckli et al. 2008). The estimated LE of the Noah LSM was overestimated while the estimated LE of the CLM was underestimated in comparison with the observations. The RMSE ranged from $60-61 \mathrm{~W} \mathrm{~m}^{-2}$ (CLM) and from $83-97 \mathrm{~W} \mathrm{~m}^{-2}$ (Noah LSM). The bias ranged from $-16-1 \mathrm{~W} \mathrm{~m}^{-2}$ (CLM) and from -34 - $28 \mathrm{~W} \mathrm{~m}^{-2}$ (Noah LSM). The $\mathrm{r}^{2}$ is 0.69 (CLM) and 0.56 (Noah LSM) for CMC and 0.48 (CLM) and 0.56 (Noah LSM) for SMC. Typically, eddy-covariance systems that measure $\mathrm{LE}$ and $\mathrm{H}$ have an average error of about $30 \mathrm{~W} \mathrm{~m}^{-2}$ due to energy closure (Twine et al. 2000). At the SMC, the $\mathrm{r}^{2}$ of the estimated LE from the Noah LSM was better than that of the CLM due to the effect of precipitation events (Fig. 4). The estimated LE from the CLM spiked immediately after (a)

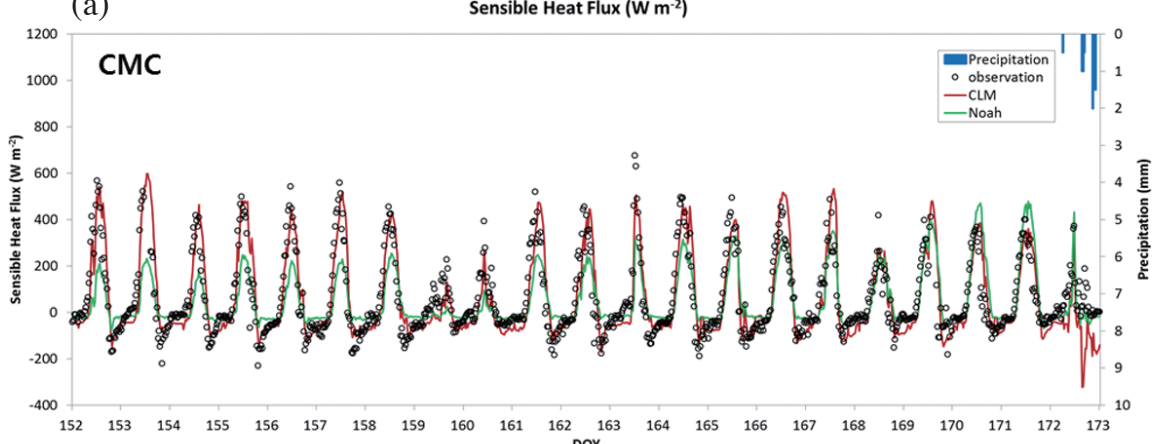

(c)

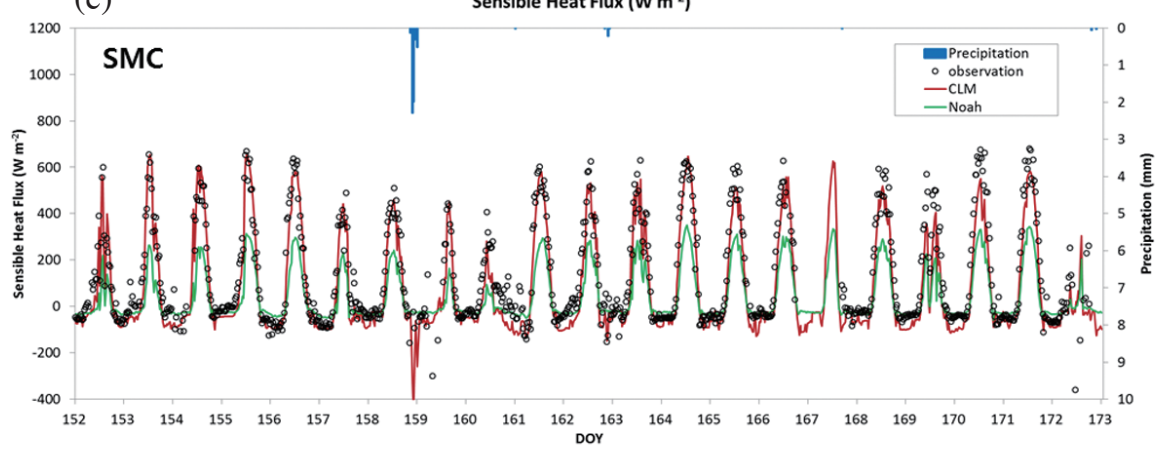

(b)

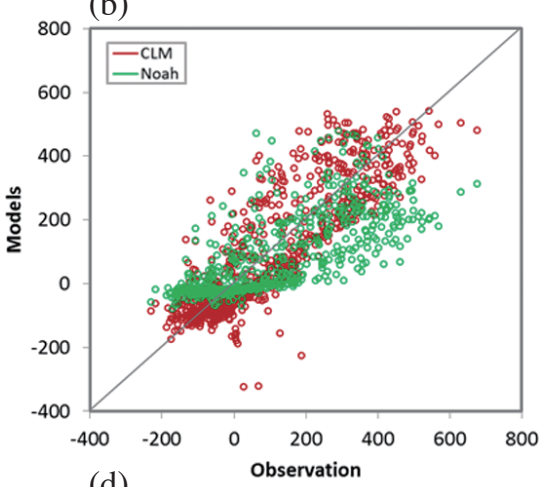

(d)

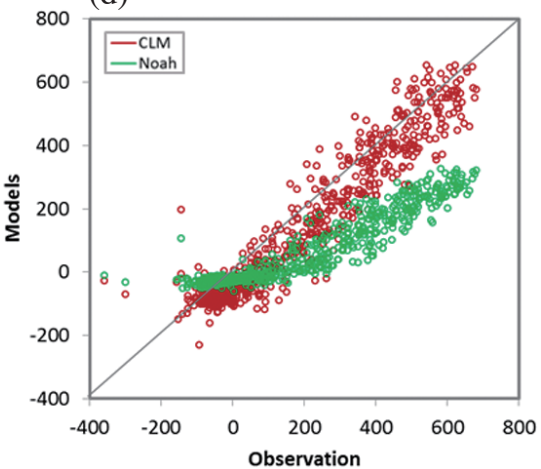

Fig. 3. Time series of observed and simulated sensible heat fluxes (H) at (a) CMC and (c) SMC and scatter plots between observed and simulated $\mathrm{H}$ at (b) CMC and (d) SMC for 31 May - 21 June 2012. (Color online only) 
Table 4. Estimated hydro-meteorological fluxes such as net radiation $\left(\mathrm{R}_{\mathrm{N}}\right)$, sensible heat flux $(H)$, latent heat flux (LE), ground heat flux $(\mathrm{G})$, and soil temperature $\left(\mathrm{T}_{\mathrm{s}}\right)$ from the CLM and Noah LSM; Statistical analysis of fluxes with initial parameters at the study sites $(y=a x+b, x=$ measurement and $y=$ estimation).

\begin{tabular}{|c|c|c|c|c|c|c|c|}
\hline Models & Land Cover Types & Variables $\left(\mathrm{W} \mathrm{m}^{-2}\right)$ & RMSE & Bias & $\mathbf{a}$ & b & $\mathbf{r}^{2}$ \\
\hline \multirow{10}{*}{ CLM } & \multirow{5}{*}{ Cropland (CMC) } & $\mathrm{R}_{\mathrm{N}}$ & 39 & 18 & 1.10 & -34.37 & 0.99 \\
\hline & & $\mathrm{H}$ & 87 & 7 & 0.93 & -2.77 & 0.77 \\
\hline & & LE & 60 & 1 & 0.69 & 26.25 & 0.69 \\
\hline & & G & 17 & 11 & 0.84 & -8.92 & 0.91 \\
\hline & & $\mathrm{T}_{\mathrm{s}}$ & 0.91 & 3.73 & 1.45 & -129.76 & 0.79 \\
\hline & \multirow{5}{*}{ Mixed Forest (SMC) } & $\mathrm{R}_{\mathrm{N}}$ & 44 & 15 & 1.13 & -38.19 & 0.99 \\
\hline & & $\mathrm{H}$ & 76 & 42 & 0.93 & -33.42 & 0.92 \\
\hline & & LE & 61 & -16 & 0.65 & 34.93 & 0.48 \\
\hline & & G & 32 & -14 & -4.59 & -17.45 & 0.10 \\
\hline & & $\mathrm{T}_{\mathrm{s}}$ & 0.92 & 0.04 & 0.66 & 98.52 & 0.77 \\
\hline \multirow{10}{*}{ Noah LSM } & \multirow{5}{*}{ Cultivations (CMC) } & $\mathrm{R}_{\mathrm{N}}$ & 50 & 39 & 0.94 & -28.58 & 0.99 \\
\hline & & $\mathrm{H}$ & 109 & 6 & 0.58 & 20.72 & 0.59 \\
\hline & & LE & 83 & 28 & 0.76 & -7.27 & 0.56 \\
\hline & & G & 21 & 5 & 0.83 & -2.95 & 0.76 \\
\hline & & $\mathrm{T}_{\mathrm{s}}$ & 7.07 & 6.98 & 1.34 & -104.93 & 0.87 \\
\hline & \multirow{5}{*}{$\begin{array}{c}\text { Broadleaf and } \\
\text { Needle-leaf Trees } \\
\text { (SMC) }\end{array}$} & $\mathrm{R}_{\mathrm{N}}$ & 45 & 37 & 1.02 & -40.11 & 0.99 \\
\hline & & $\mathrm{H}$ & 151 & 87 & 0.46 & -16.46 & 0.90 \\
\hline & & LE & 97 & -34 & 1.28 & 18.91 & 0.56 \\
\hline & & G & 48 & -17 & 1.88 & 21.91 & 0.01 \\
\hline & & $\mathrm{T}_{\mathrm{s}}$ & 3.73 & 3.21 & 2.51 & -440.18 & 0.85 \\
\hline
\end{tabular}

(a)

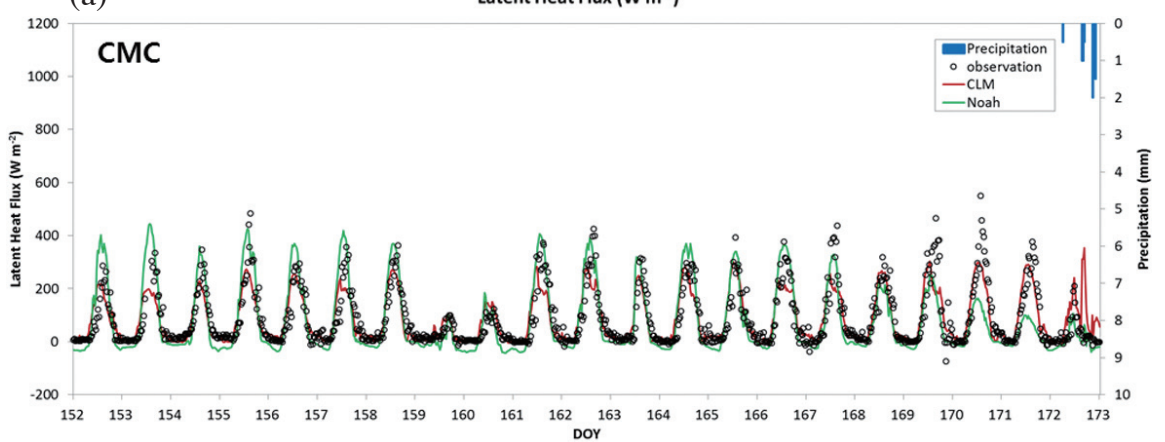

(c)

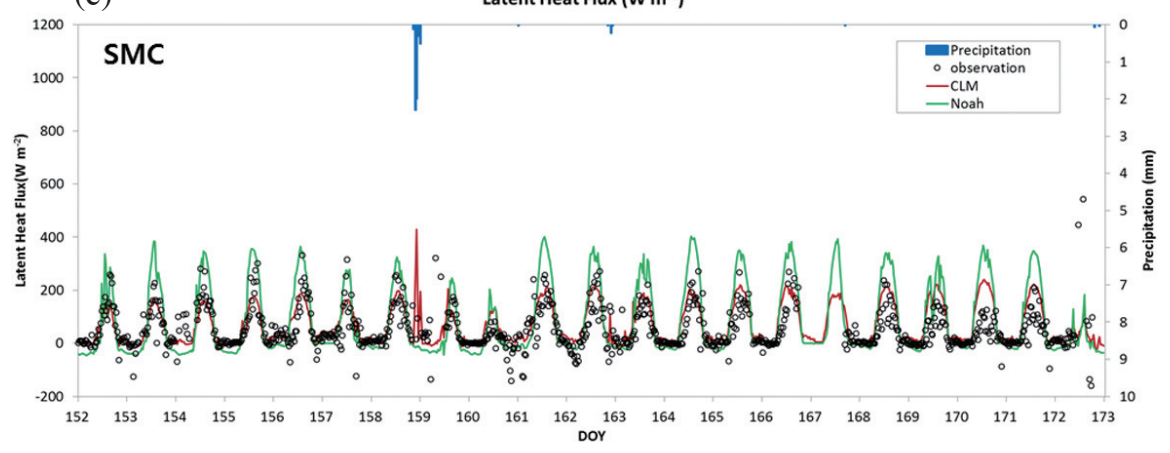

(b)

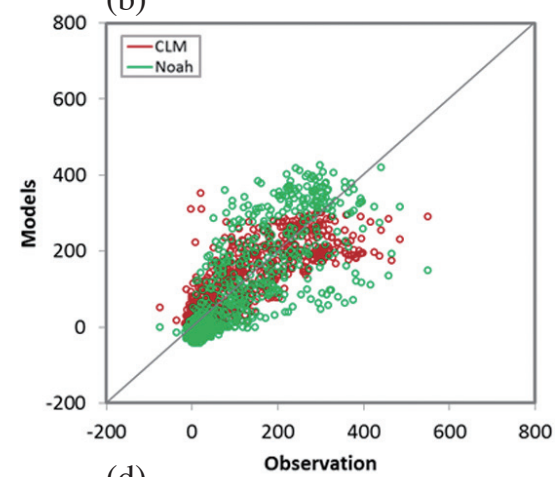

(d)

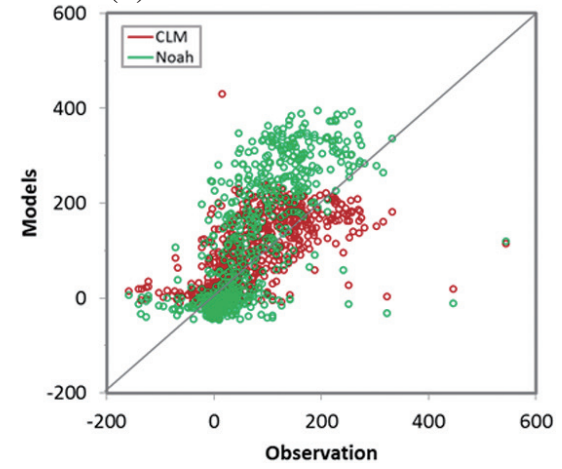

Fig. 4. Time series of observed and simulated latent heat fluxes (LE) at (a) CMC and (c) SMC and scatter plots between observed and simulated LE at (b) CMC and (d) SMC for 31 May - 21 June 2012. (Color online only) 
the rainfall events, in contrast with the estimated H. Under the wet surface condition, the overestimated LE is highly connected with precipitation related to water table changes (Comer et al. 2000). In the case of the estimated LE from the Noah LSM, spiking patterns did not arise during the rainfall period. In general, the CLM showed more sound agreement with the observations with a relatively better RMSE and bias at the SMC site in comparison with the Noah LSM. Therefore, the estimated $\mathrm{H}$ and LE from using the CLM generally show more effective results than those from the Noah LSM (Figs. 3 and 4, and Table 4). According to the site locations, the LE statistics at CMC are a better result than those at SMC, although the $\mathrm{r}^{2}$ values from the Noah LSM showed the occurrence of the same values at both sites.

Kahan et al. (2006) found that the over- and underestimations of $\mathrm{H}$ and LE from the Simplified Simple Biosphere Model ( $\mathrm{SSiB}$ ) at Sahelian in Niger were influenced by the model stomatal resistance. In wetland conditions Verseghy et al. (1993) suggested that the resistance functions needed to be adjusted to reduce the consistent evapotranspiration errors. In addition, Van der Velde et al. (2009) stated that soil-thermal-properties parameter adjustment and vegetation parameters calibration of the minimum stomatal resistance and optimum temperature reduced the transpiration uncertainties in the simulated H and LE in the Noah LSM.

The $\mathrm{G}$ is also a major component of energy balance equation. The diurnal variations of the estimated $\mathrm{G}$ from the both models at CMC are in sound agreement with the observations. The observed $\mathrm{G}$ at SMC shows relatively small values during the study period (Fig. 5a) because the ground surface heat flux in dense forests is barely about $3-6 \%$ of the $\mathrm{R}_{\mathrm{N}}$ above the canopy (Van der Meulen and Klaassen 1996). Especially, this impact was great at the growing season based on talks with field investigators. In addition, Oliver et al. (1987) also referred that the solar radiation intercepted by the vegetation resulted in low G fluctuation, thus, the observed $\mathrm{G}$ was considered underestimated values. However, the $\mathrm{G}$ is a residual value $(\mathrm{G}=$ solar radiation-net longwave radiation-H-LE), thus, the estimated $\mathrm{G}$ at SMC could be assumed that it was a reliable value because the estimated $\mathrm{H}$ and LE showed relatively good results at SMC. In addition, the G from CLM and Noah LSM showed similar results each other, thus, the $G$ values based on the energy balance equation was reliable in principle. The RMSE and bias are 17 and $11 \mathrm{~W} \mathrm{~m}^{-2}$ (CLM), and 21 and $5 \mathrm{~W} \mathrm{~m}^{-2}$ (Noah $\mathrm{LSM}$ ) at CMC, respectively, and 32 and $-14 \mathrm{~W} \mathrm{~m}^{-2}$ (CLM) and 48 and $-17 \mathrm{~W} \mathrm{~m}^{-2}$ (Noah LSM) at SMC, respectively. The $\mathrm{r}^{2}$ are 0.91 (CLM) and 0.76 (Noah LSM) at CMC, and 0.10 (CLM) and 0.01 (Noah LSM) at SMC (Table 4).

The temporal variations in $T_{\mathrm{s}}$ are presented in Fig. 6 . While the estimated $\mathrm{T}_{\mathrm{s}}$ from CLM were overestimated, the estimated $\mathrm{T}_{\mathrm{s}}$ from Noah LSM were underestimated in comparison with the in situ data. The RMSE and bias ranged from $0.91-0.92 \mathrm{~K}$ and from $0.04-3.73 \mathrm{~K}$ for CLM, and ranged from $3.73-7.07 \mathrm{~K}$ and from $3.21-6.98 \mathrm{~K}$ for Noah LSM (Table 4). The $\mathrm{r}^{2}$ ranged from $0.77-0.79$ (CLM) and from $0.85-0.87$ (Noah LSM). Although the $\mathrm{r}^{2}$ values between the estimated $\mathrm{T}_{\mathrm{s}}$ from the Noah LSM and the observations were better than those of the CLM, the other statistical analysis values such as the RMSE and bias from the Noah LSM were worse than those from the CLM. The clear increase patterns of observed $T_{s}$ and estimated $T_{s}$ from the Noah LSM was probably causative of better $\mathrm{r}^{2}$ values, while the $\mathrm{T}_{\mathrm{s}}$ from the CLM appeared modest increase patterns relatively. The better RMSE and bias for the CLM with observations were also evident in Fig. 6. There were clear differences between the CLM and the Noah LSM. The estimated $\mathrm{T}_{\mathrm{s}}$ from both models, however, had similar diurnal fluctuating patterns to those of the observations, even though the differences between $T_{s}$ from the Noah LSM and observed $\mathrm{T}_{\mathrm{s}}$ showed relatively large differences. The daily maximum values were observed in the afternoon during the dry period and relatively small fluctuations of temperature were observed during the rainy period. The difference between the daily maximum and minimum values is about $2.5 \mathrm{~K}$ at each site. The $\mathrm{T}_{\mathrm{s}}$ is interrelated with soil moisture, since soil moisture errors are caused by erroneous soil heat capacity and incorrect thermal energy transport in the soil (Whitfield et al. 2006); in addition, the soil respiration related to $T_{\mathrm{s}}$ influences the soil moisture (Davidson et al. 1998). A proportional relationship exists between evapo-transpiration and $\mathrm{T}_{\mathrm{s}}$ (Breshears et al. 1998). The runoff can also be affected by $T_{s}$, especially during snowmelt season (Nakayama and Watanabe 2006). In default Noah LSM parameterization the soil vertical heterogeneity was not considered. According to this the soil temperature was influenced by the estimated error (Van der Velde et al. 2009). Yang et al. (2008) also showed that the Zilitinkevich (1995) scheme in the Noah LSM overestimated the roughness length, consequently leading to underestimated surface-temperature peak values.

In terms of RMSE and bias, both models at CMC performed relatively better than those at SMC due to environmental factors like terrain type and vegetation conditions. The observed and simulated hydro-meteorological fluxes that were acquired under stable conditions such as flat and farmland (e.g., CMC) are relatively sound compared with the forest condition (e.g., SMC). In addition, both models could simulate quite reasonable results based on the preceding analysis of the figures and tables showing the statistical results, and the CLM shows relatively better statistical results such as RMSE and bias.

\subsection{Sensitivity Analysis}

In this experiment the parameterizations of vegetation classification and soil texture were selected to assess the model sensitivity. First, the International Geosphere-Biosphere Programme (IGBP) land-cover classifications in the 
(a)

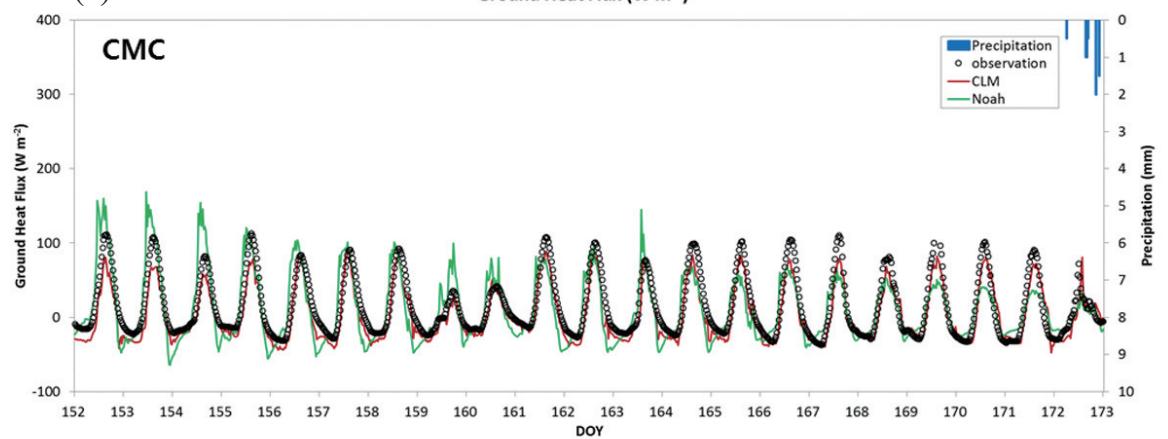

(c)

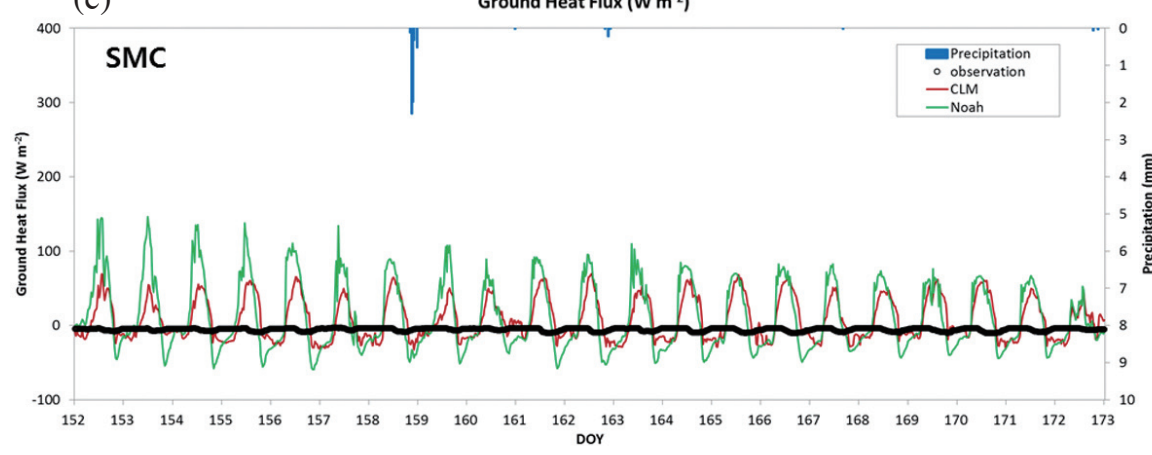

(b)

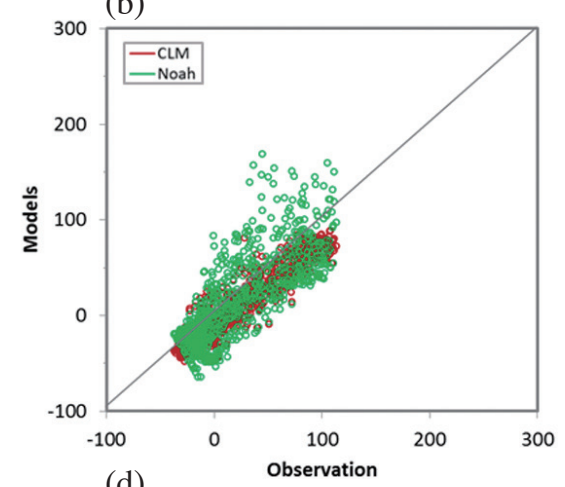

(d)

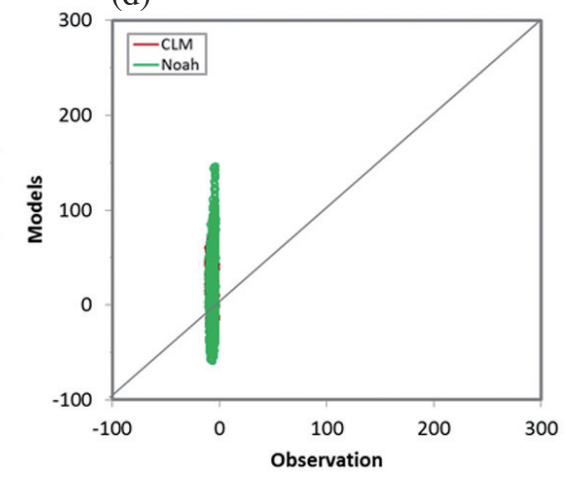

Fig. 5. Time series of observed and simulated ground heat fluxes (G) at (a) CMC and (c) SMC and scatter plots between observed and simulated $\mathrm{G}$ at (b) CMC and (d) SMC for 31 May - 21 June 2012. (Color online only)

(a)

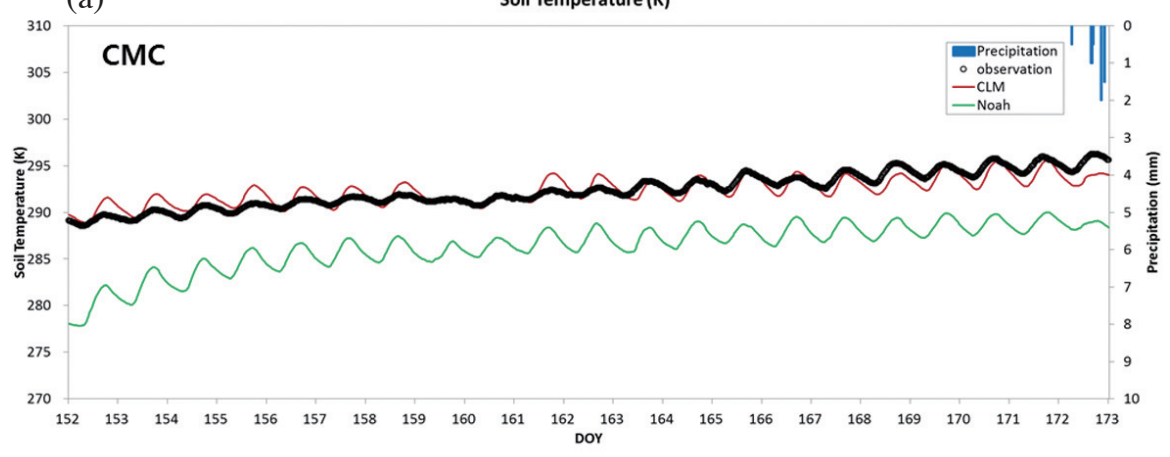

(c)

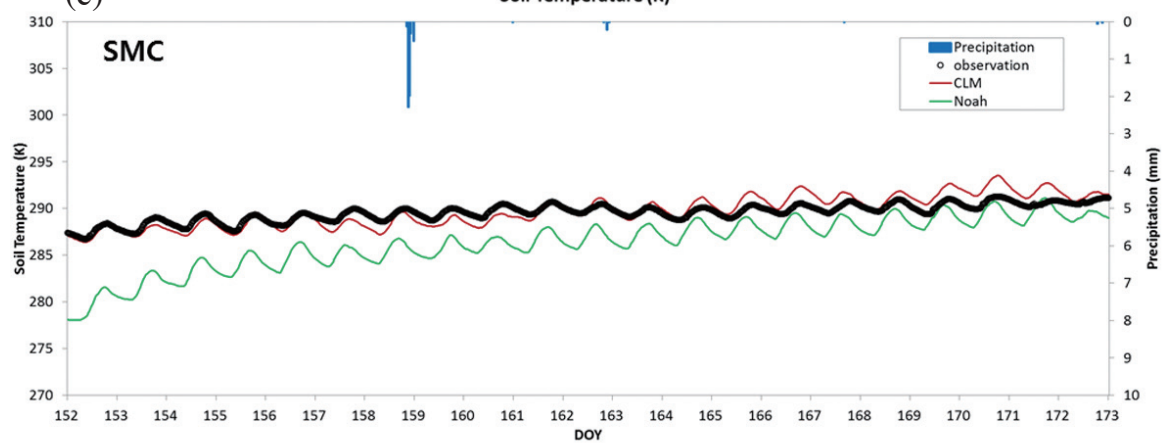

(b)
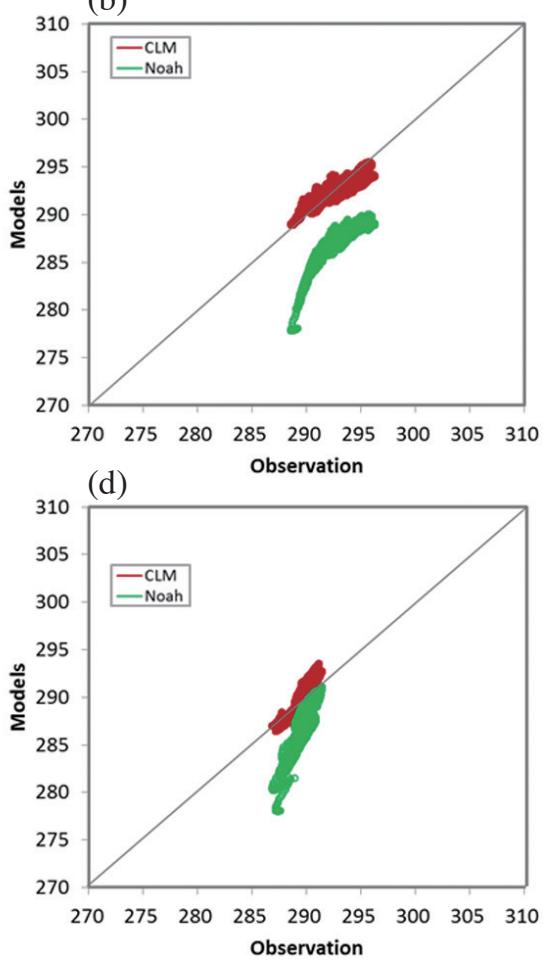

Fig. 6. Time series of observed and simulated soil temperatures ( $\mathrm{T}_{\mathrm{s}}$ ) at (a) CMC and (c) SMC and scatter plots between observed and simulated $\mathrm{T}_{\mathrm{s}}$ at (b) CMC and (d) SMC for 31 May - 21 June 2012. (Color online only) 
CLM (cropland and mixed forest were initially chosen at CMC and SMC) were adjusted to cropland/natural vegetation mosaic (CMC) and evergreen needle-leaf forests/deciduous broad-leaf forests (SMC) to investigate how land-cover classification affects the model performance. Generally, the CLM responded more sensitively than the Noah LSM with a modification of the land-cover types (Table 5). The RMSEs of $R_{N}, H, L E$, and $T_{s}$ increased by approximately $0-24 \mathrm{~W} \mathrm{~m}^{-2}$ (Table 5) with adjusted land-cover classifications (cropland/natural vegetation mosaic and evergreen needle-leaf forests/deciduous broad-leaf forests at CMC and SMC) from the vegetation conditions that we originally chose. In the Noah LSM we modified the land-cover types from cultivation (CMC) and broad- and needle-leaf trees (SMC) into broad-leaf and deciduous trees and ground cover, but only to consider the land-cover heterogeneity across the study sites. As was previously described the Noah LSM was numerically less susceptible to land-cover changes (Table 5). The statistical Noah LSM statistical results show relatively few changes in the RMSE and bias, unlike the general CLM results. Secondly, the percentage of sand and clay was modified $\pm 10 \%$ from the initial values up to $\pm 50 \%$ for the soil texture influence on CLM performance. The results show that $\mathrm{H}$ is more sensitive than the other fluxes such as $L E$ and $T_{s}$ (Fig. 7). The normalization of $\mathrm{H}$ and $\mathrm{LE}$ were fluctuated by approximately $0.5 \%$ with variations in sand and clay percentages and a clay-percentage increase shows a particularly positive impact in contrast to the sandpercentage increase that induced a negative pattern (Fig. 7). Furthermore, the LE normalization shows a counter trend to the percentage adjustments for both sand and clay and was relatively less susceptible to the soil texture. The $\mathrm{T}_{\mathrm{s}}$ was unperturbed by the soil texture and remained mainly unaffected by the clay percentage in particular. Peters-Lidard et al. (1998) found that the H, LE, and $T_{\mathrm{s}}$ depended on soil characteristics such as thermal conductivity that are different from soil texture.

Thirdly, the soil texture in the Noah LSM was derived from Zobler's soil-class categories (Zobler 1986), which are comprised of 9 soil textures. Therefore, the soil texture sensitivity analysis was conducted to modify the Zobler soil class in each category in Fig. 8. The sensitivity test results for the Noah LSM show a relatively large distinction depending on the soil-class number selection which was fixed in the model instead of entering the soil texture percentage. In the Noah LSM, energy fluxes especially showed sensitive reactions to each number of soil classifications. The $\mathrm{H}$ was the most sensitive among the other fluxes, whereas the normalization

Table 5. The variation in estimated fluxes in the CLM and Noah LSM for sensitivity analysis; the variation of statistical analysis for fluxes $(|\Delta|)$ with modified land cover types at the study sites $(y=$ $\mathrm{ax}+\mathrm{b}, \mathrm{x}=$ measurement and $\mathrm{y}=$ estimation).

\begin{tabular}{|c|c|c|c|c|c|}
\hline Models & Land Cover Types & Variables $^{\mathrm{a}}$ & 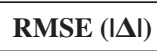 & $\operatorname{Bias}(|\Delta|)$ & $\mathbf{r}^{2}(|\Delta|)$ \\
\hline \multirow{10}{*}{ CLM } & \multirow{5}{*}{$\begin{array}{c}\text { Cropland/Natural Vegetation } \\
\text { Mosaic (CMC) }\end{array}$} & $\mathrm{R}_{\mathrm{N}}$ & 14 & 0 & 0.00 \\
\hline & & $\mathrm{H}$ & 1 & 46 & 0.15 \\
\hline & & LE & 7 & 26 & 0.25 \\
\hline & & G & 9 & 25 & 0.76 \\
\hline & & $\mathrm{T}_{\mathrm{s}}$ & 0.18 & 3.13 & 0.01 \\
\hline & \multirow{5}{*}{$\begin{array}{l}\text { Evergreen Needle-leaf Forests } \\
\text { and Deciduous Broad-leaf } \\
\text { Forests (SMC) }\end{array}$} & $\mathrm{R}_{\mathrm{N}}$ & 0 & 6 & 0.00 \\
\hline & & $\mathrm{H}$ & 24 & 44 & 0.14 \\
\hline & & LE & 24 & 26 & 0.20 \\
\hline & & $\mathrm{G}$ & 8 & 62 & 0.05 \\
\hline & & $\mathrm{T}_{\mathrm{s}}$ & 0.11 & 0.04 & 0.08 \\
\hline \multirow{10}{*}{ Noah LSM } & \multirow{5}{*}{ Groundcover Only (CMC) } & $\mathrm{R}_{\mathrm{N}}$ & 6 & 5 & 0.00 \\
\hline & & $\mathrm{H}$ & 1 & 6 & 0.01 \\
\hline & & LE & 3 & 1 & 0.03 \\
\hline & & $\mathrm{G}$ & 0 & 0 & 0.00 \\
\hline & & $\mathrm{T}_{\mathrm{s}}$ & 0.07 & 0.07 & 0.00 \\
\hline & \multirow{5}{*}{$\begin{array}{c}\text { Broad-leaf and Deciduous } \\
\text { Trees (SMC) }\end{array}$} & $\mathrm{R}_{\mathrm{N}}$ & 6 & 8 & 0.00 \\
\hline & & $\mathrm{H}$ & 13 & 9 & 0.00 \\
\hline & & LE & 2 & 1 & 0.00 \\
\hline & & $\mathrm{G}$ & 1 & 0 & 0.00 \\
\hline & & $\mathrm{T}_{\mathrm{s}}$ & 0.03 & 0.04 & 0.00 \\
\hline
\end{tabular}

Note: a: Units of the $R_{N}, H, L E$, and $G$ are $W m^{-2}$. Unit of the $T_{s}$ is $K$. 

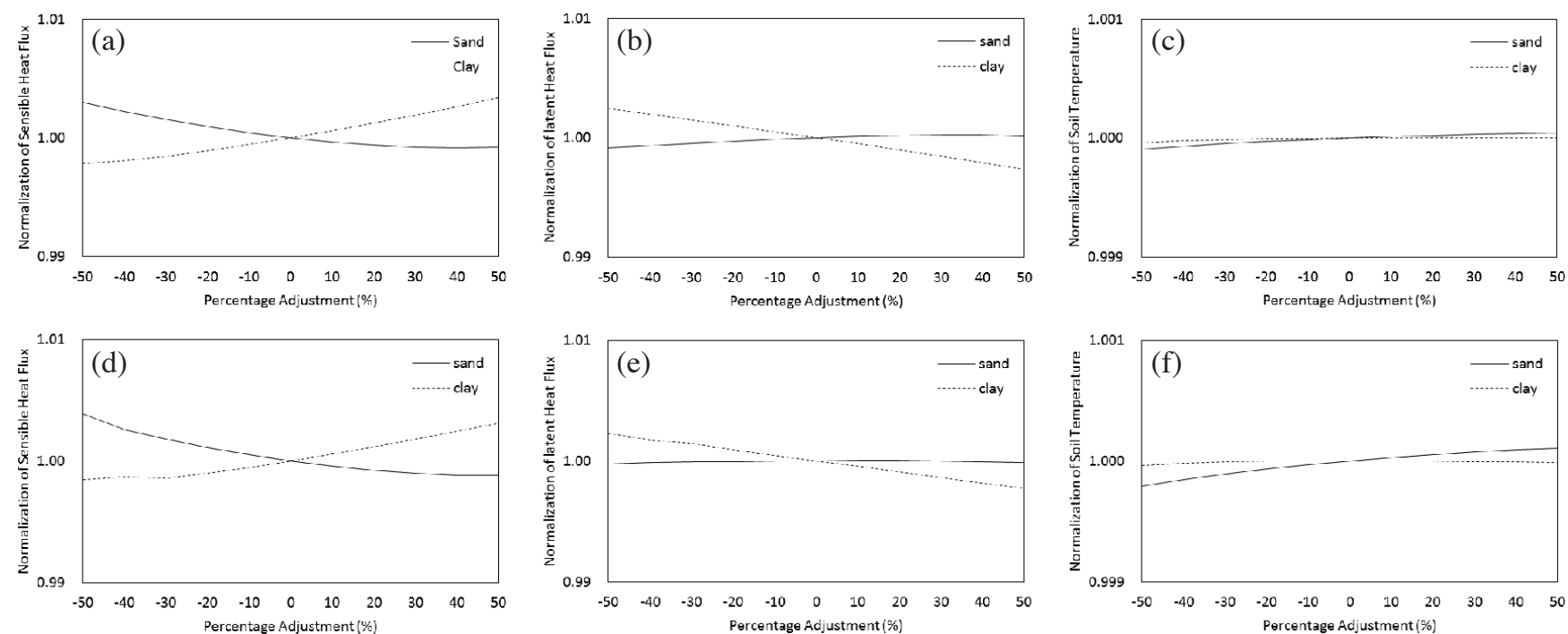

Fig. 7. Sensitivity analysis for the CLM according to percentage adjustment of soil texture at CMC [normalization of (a) H, (b) LE, and (c) $\mathrm{T}_{\mathrm{s}}$ ] and SMC [normalization of (d) H, (e) LE, and (f) $\mathrm{T}_{\mathrm{s}}$ ].
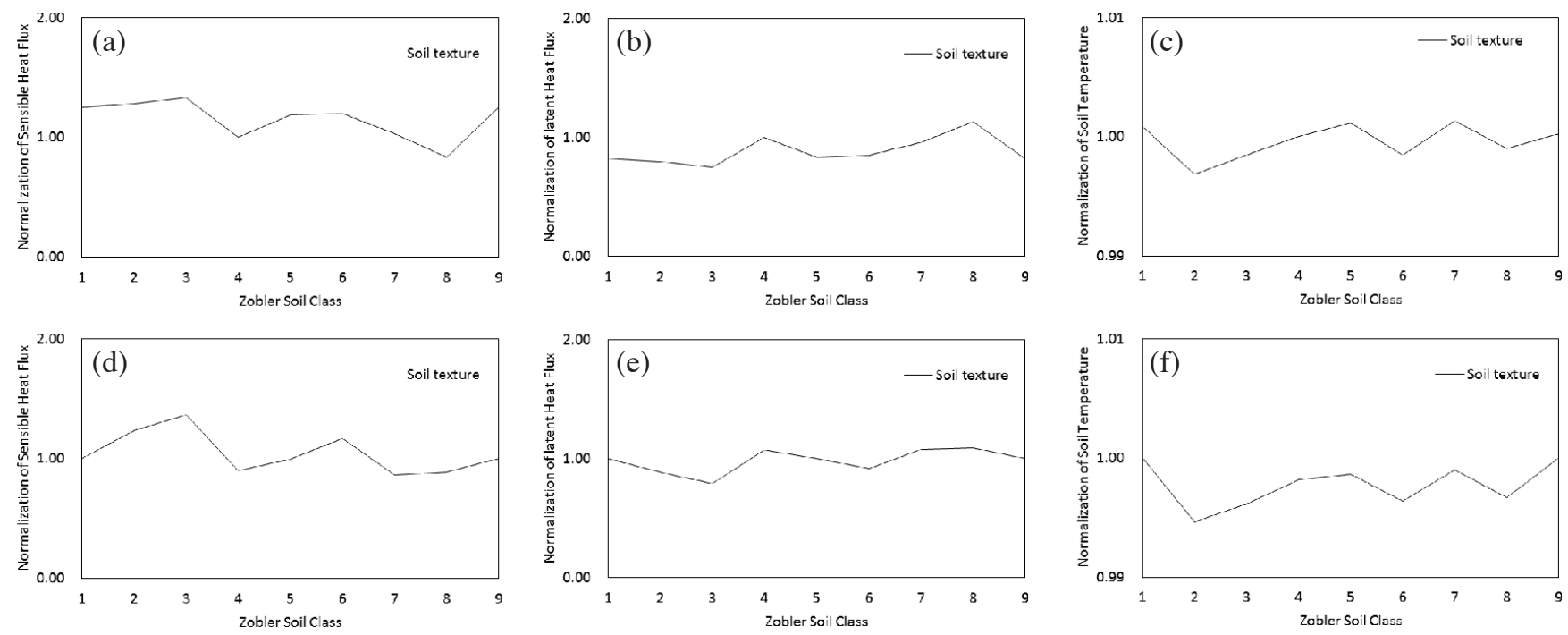

Fig. 8. Sensitivity analysis for the Noah LSM according to modification of soil class categories at CMC [normalization of (a) H, (b) LE, and (c) $\mathrm{T}_{\mathrm{s}}$ ] and SMC [normalization of (d) H, (e) LE, and (f) $\mathrm{T}_{\mathrm{s}}$ ].

of $\mathrm{T}_{\mathrm{s}}$ was altered within a $0.5 \%$ range (Fig. 8). In addition, the normalization of $\mathrm{H}$ and LE showed opposite tendencies that are common with prior results. These Noah LSM sensitivity-analysis results signified that the Zobler soil class was limited in its reflection of an accurate soil state because the categorization was coarse without a detailed percentage adjustment of the soil texture. In addition, the Zobler soil class also had a duplicate division for loamy sand according to the classification descriptions. The soil texture analysis effect for the Noah LSM was therefore inaccessible. Wilson et al. (1987) conducted sensitivity experiments on the effects of soil texture and vegetation and mentioned that the largest change in the model's results occurred when the soil texture was altered. Mihailovic et al. (1992) also indicated a strong connection between the soil texture and turbulent fluxes in comparison with other land parameterizations. Jacquemin and Noilhan (1990) identified that the soil texture considerably influenced the fluxes. We also analyzed the flux changes according to albedo, and only the $\mathrm{H}$ showed a meaningful alteration that was inversely proportional to the albedo (changed approximately $35 \%$ with $\mathrm{H}$ according to a 0.08 change with albedo).

\section{CONCLUSIONS}

We compared the estimated hydrometeorological fluxes 
such as $R_{N}, H, L E, G$, and $T_{s}$ from the CLM and Noah LSM offline modeling systems over 21 days during the early summer monsoon season at the CMC and SMC sites in Korea. The fluxes estimated from both models were compared with in situ data from the HSC. In addition, the sensitivity analyses were performed to examine how land-cover classifications and soil texture affect the fluxes from both models. The results from this study showed that the CLM simulates more reasonable hydro-meteorological fluxes than the Noah LSM. The estimated fluxes such as $\mathrm{R}_{\mathrm{N}}, \mathrm{H}, \mathrm{LE}$, and $\mathrm{G}$ from both models at the CMC site show relatively better results in comparison with the estimations at SMC due to environmental factors including terrain type and vegetation condition. Overall, this study demonstrated that the CLM is far more applicable in Korea during the monsoon period than the Noah LSM. In accordance with the sensitivity analysis, the CLM was more sensitive to land-cover types than the Noah LSM. In addition, the soil texture had a greater influence on the $R_{N}, H, L E$, and $G$ than the $T_{s}$ of both models. Further research studies, such as those on the hydro-meteorological flux parameterizations for both models under a variety of field conditions, should be conducted to improve the models' applicability at various sites, as these will allow for an improved understanding of the interaction between the land surface and atmosphere.

Acknowledgements This research was supported by Space Core Technology Development Program through the National Research Foundation of Korea (NRF) funded by the Ministry of Science, ICT and Future Planning (NRF2014M1A3A3A02034789). The authors wish to thank the Hydrological Survey Center (HSC) in Korea for providing hydro-meteorological data.

\section{REFERENCES}

Avissar, R. and R. A. Pielke, 1989: A parameterization of heterogeneous land surfaces for atmospheric numerical models and its impact on regional meteorology. Mon. Weather Rev., 117, 2113-2136, doi: 10.1175/15200493(1989)117<2113:APOHLS>2.0.CO;2. [Link]

Bastidas, L. A., H. V. Gupta, K. Hsu, and S. Sorooshian, 2003: Parameter, structure, and model performance evaluation for land-surface schemes. In: Duan, Q., H. V. Gupta, S. Sorooshian, A. N. Rousseau and R. Turcotte (Eds.), Calibration of Watershed Models American Geophysical Union, Washington, D. C., 229-237.

Beven, K. J. and M. J. Kirkby, 1979: A physically based, variable contributing area model of basin hydrology. Hydrol. Sci. Bull., 24, 43-69, doi: 10.1080/02626667909491834. [Link]

Bonan, G. B., K. W. Oleson, M. Vertenstein, S. Levis, X. Zeng, Y. Dai, R. E. Dickinson, and Z. L. Yang, 2002: The land surface climatology of the community land model coupled to the NCAR community climate model. J. Climate, 15, 3123-3149, doi: 10.1175/1520-0442 (2002)015<3123:TLSCOT>2.0.CO;2. [Link]

Breshears, D. D., J. W. Nyhan, C. E. Heil, and B. P. Wilcox, 1998: Effects of woody plants on microclimate in a semiarid woodland: Soil temperature and evaporation in canopy and intercanopy patches. Int. J. Plant Sci., 159, 1010-1017, doi: 10.1086/314083. [Link]

Brutsaert, W., 1982: Evaporation into the Atmosphere: Theory, History, and Applications, Springer Netherlands, doi: 10.1007/978-94-017-1497-6. [Link]

Chen, F., K. Mitchell, J. Schaake, Y. Xue, H. L. Pan, V. Koren, Q. Y. Duan, M. Ek, and A. Betts, 1996: Modeling of land surface evaporation by four schemes and comparison with FIFE observations. J. Geophys. Res., 101, 7251-7268, doi: 10.1029/95JD02165. [Link]

Chen, F., Z. Janjić, and K. Mitchell, 1997: Impact of atmospheric surface-layer parameterizations in the new land-surface scheme of the NCEP mesoscale Eta model. Bound.-Layer Meteor., 85, 391-421, doi: 10.1023/ A: 1000531001463 . [Link]

Choi, M., S. O. Lee, and H. Kwon, 2010: Understanding of the Common Land Model performance for water and energy fluxes in a farmland during the growing season in Korea. Hydrol. Process., 24, 1063-1071, doi: 10.1002/hyp.7567. [Link]

Clapp, R. B. and G. M. Hornberger, 1978: Empirical equations for some soil hydraulic properties. Water Resour. Res., 14, 601-604, doi: 10.1029/WR014i004p00601. [Link]

Collatz, G. J., J. T. Ball, C. Grivet, and J. A. Berry, 1991: Physiological and environmental regulation of stomatal conductance, photosynthesis and transpiration: A model that includes a laminar boundary layer. $A g$ ric. For. Meteorol., 54, 107-136, doi: 10.1016/01681923(91)90002-8. [Link]

Comer, N. T., P. M. Lafleur, N. T. Roulet, M. G. Letts, M. Skarupa, and D. Verseghy, 2000: A test of the Canadian Land Surface Scheme (CLASS) for a variety of wetland types. Atmos.-Ocean, 38, 161-179, doi: 10.1080/07055900.2000.9649644. [Link]

Dai, Y., X. Zeng, R. E. Dickinson, I. Baker, G. B. Bonan, M. G. Bosilovich, A. S. Denning, P. A. Dirmeyer, P. R. Houser, G. Niu, K. W. Oleson, C. A. Schlosser, and Z. L. Yang, 2003: The Common Land Model. Bull.Amer. Meteorol. Soc., 84, 1013-1023, doi: 10.1175/BAMS84-8-1013. [Link]

Davidson, E. A., E. Belk, and R. D. Boone, 1998: Soil water content and temperature as independent or confounded factors controlling soil respiration in a temperate mixed hardwood forest. Global Change Biol., 4, 217-227, doi: 10.1046/j.1365-2486.1998.00128.x. [Link]

De Haan, L. L., M. Kanamitsu, C. H. Lu, and J. O. Roads, 2007: A comparison of the Noah and OSU Land 
Surface Models in the ECPC Seasonal Forecast Model. J. Hydrometeorol., 8, 1031-1048, doi: 10.1175/ JHM629.1. [Link]

Ek, M. B., K. E. Mitchell, Y. Lin, E. Rogers, P. Grunmann, V. Koren, G. Gayno, and J. D. Tarpley, 2003: Implementation of Noah land surface model advances in the National Centers for Environmental Prediction operational mesoscale Eta model. J. Geophys. Res., 108, doi: 10.1029/2002JD003296. [Link]

Farouki, O. T., 1981: Thermal properties of soils. CRREL Monograph 81-1, United States Army Corps of Engineers, Cold Regions Research and Engineering Laboratory, Hanover, New Hampshire, U.S.A.

Han, Z., H. Ueda, and J. An, 2008: Evaluation and intercomparison of meteorological predictions by five MM5-PBL parameterizations in combination with three land-surface models. Atmos. Environ., 42, 233249, doi: 10.1016/j.atmosenv.2007.09.053. [Link]

Hogue, T. S., L. Bastidas, H. Gupta, S. Sorooshian, K. Mitchell, and W. Emmerich, 2005: Evaluation and transferability of the Noah land surface model in semiarid environments. J. Hydrometeorol., 6, 68-84, doi: 10.1175/JHM-402.1. [Link]

Huang, C., X. Li, J. Wang, and J. Gu, 2008: Assimilation of remote sensing data products into common land model for evapotranspiration forecasting. Proceedings of the 8th International Symposium on Spatial Accuracy Assessment in Natural Resources and Environmental Sciences, World Academic Union, Shanghai Liverpool, China, 234-241.

Jacquemin, B. and J. Noilhan, 1990: Sensitivity study and validation of a land surface parameterization using the HAPEX-MOBILHY data set. Bound-Layer Meteor., 52, 93-134, doi: 10.1007/BF00123180. [Link]

Jang, S., M. Cho, J. Yoon, Y. Yoon, S. Kim, G. Kim, L. Kim, and H. Aksoy, 2007: Using SWMM as a tool for hydrologic impact assessment. Desalination, 212, 344356, doi: 10.1016/j.desal.2007.05.005. [Link]

Kahan, D. S., Y. Xue, and S. J. Allen, 2006: The impact of vegetation and soil parameters in simulations of surface energy and water balance in the semi-arid sahel: A case study using SEBEX and HAPEXSahel data. J. Hydrol., 320, 238-259, doi: 10.1016/j. jhydrol.2005.07.011. [Link]

Kato, H., M. Rodell, F. Beyrich, H. Cleugh, E. van Gorsel, H. Liu, and T. P. Meyers, 2007: Sensitivity of land surface simulations to model physics, land characteristics, and forcings, at four CEOP sites. J.Meteorol. Soc.Jpn., 85A, 187-204, doi: 10.2151/jmsj.85A.187. [Link]

Koren, V., J. Schaake, K. Mitchell, Q. Y. Duan, F. Chen, and J. M. Baker, 1999: A parameterization of snowpack and frozen ground intended for NCEP weather and climate models. J. Geophys. Res., 104, 1956919585, doi: 10.1029/1999JD900232. [Link]
Kwon, H., S. Park, M. Kang, J. Yoo, R. Yuan, and J. Kim, 2007: Quality control and assurance of eddy covariance data at the two KoFlux sites. Korean J.Agric. For. Meteorol., 9, 260-267, doi: 10.5532/KJAFM.2007.9. 4.260. [Link]

Kwon, H., T. Y. Park, J. Hong, J. H. Lim, and J. Kim, 2009: Seasonality of net ecosystem carbon exchange in two major plant functional types in Korea. Asia Pac. J. Atmos. Sci., 45, 149-163.

Lawrence, P. J. and T. N. Chase, 2007: Representing a new MODIS consistent land surface in the Community Land Model (CLM 3.0). J. Geophys. Res., 112, G01023, doi: 10.1029/2006JG000168. [Link]

Li, B. and R. Avissar, 1994: The impact of spatial variability of land-surface characteristics on land-surface heat fluxes. J. Climate, 7, 527-537, doi: 10.1175/15200442(1994)007<0527:TIOSVO>2.0.CO;2. [Link]

Li, Z., Z. Wei, C. Wang, Z. Zheng, H. Wei, and H. Liu, 2012: Simulation and improvement of common land model on the bare soil of Loess Plateau underlying surface. Environ. Earth Sci., 66, 1091-1097, doi: 10.1007/ s12665-011-1315-2. [Link]

Liang, X. and J. Guo, 2003: Intercomparison of land-surface parameterization schemes: Sensitivity of surface energy and water fluxes to model parameters. J. Hydrol., 279, 182-209, doi: 10.1016/S0022-1694(03)00168-9. [Link]

Liang, X., D. P. Lettenmaier, E. F. Wood, and S. J. Burges, 1994: A simple hydrologically based model of land surface water and energy fluxes for general circulation models. J. Geophys. Res., 99, 14415-14428, doi: 10.1029/94JD00483. [Link]

Mahrt, L. and M. Ek, 1984: The influence of atmospheric stability on potential evaporation. J. Clim. Appl. Meteorol., 23, 222-234, doi: 10.1175/1520-0450(1984)023<0222:TIOASO>2.0.CO;2. [Link]

Mahrt, L. and H. Pan, 1984: A two-layer model of soil hydrology. Bound.-Layer Meteor., 29, 1-20, doi: 10.1007/ BF00119116. [Link]

Meng, C. L., Z. L. Li, X. Zhan, J. C. Shi, and C. Y. Liu, 2009: Land surface temperature data assimilation and its impact on evapotranspiration estimates from the Common Land Model. Water Resour. Res., 45, W02421, doi: 10.1029/2008WR006971. [Link]

Mihailovic, D. T., H. A. R. de Bruin, M. Jeftic, and A. van Dijken, 1992: A study of the sensitivity of land surface parameterizations to the inclusion of different fractional covers and soil textures. J. Appl. Meteorol., 31, 1477-1487, doi: 10.1175/1520-0450(1992)031<1477:ASOTSO>2.0.CO;2. [Link]

Mitchell, K., 2005: The Community Noah Land-Surface Model (LSM), User's Guide, Public Release Version 2.7.1. Available at ftp://ftp.emc.ncep.noaa.gov/mmb/ gcp/ldas/noahlsm/ver_2.7.1. 
Nakayama, T. and M. Watanabe, 2006: Simulation of spring snowmelt runoff by considering micro-topography and phase changes in soil layer. Hydrol. Earth Syst. Sci., 3, 2101-2144, doi: 10.5194/hessd-3-2101-2006. [Link]

Niu, G. Y. and Z. L. Yang, 2006: Assessing a land surface model's improvements with GRACE estimates. Geophys. Res. Lett., 33, L07401, doi: 10.1029/2005GL025555. [Link]

Niu, G. Y., Z. L. Yang, K. E. Mitchell, F. Chen, M. B. Ek, M. Barlage, A. Kumar, K. Manning, D. Niyogi, E. Rosero, M. Tewari, and Y. Xia, 2011: The community Noah land surface model with multiparameterization options (Noah-MP): 1. Model description and evaluation with local-scale measurements. J. Geophys. Res., 116, D12109, doi: 10.1029/2010JD015139. [Link]

Oleson, K. W., K. L. Driese, J. A. Maslanik, W. J. Emery, and W. A. Reiners, 1997: The sensitivity of a land surface parameterization scheme to the choice of remotely sensed land-cover datasets. Mon. Weather Rev., 125, 1537-1555, doi: 10.1175/1520-0493(1997)125<1537: TSOALS $>2.0 . \mathrm{CO} ; 2$. [Link]

Oliver, S. A., H. R. Oliver, J. S. Wallace, and A. M. Roberts, 1987: Soil heat flux and temperature variation with vegetation, soil type and climate. Agric. For. Meteorol., 39, 257-269, doi: 10.1016/0168-1923(87)90042-6. [Link]

Pan, H. L. and L. Mahrt, 1987: Interaction between soil hydrology and boundary-layer development. Bound.-Layer Meteor., 38, 185-202, doi: 10.1007/BF00121563. [Link]

Patil, M. N., R. T. Waghmare, S. Halder, and T. Dharmaraj, 2011: Performance of Noah land surface model over the tropical semi-arid conditions in western India. Atmos. Res., 99, 85-96, doi: 10.1016/j.atmosres.2010.09.006. [Link]

Peters-Lidard, C. D., M. S. Zion, and E. F. Wood, 1997: A soil-vegetation-atmosphere transfer scheme for modeling spatially variable water and energy balance processes. J. Geophys. Res., 102, 4303-4324, doi: 10.1029/96JD02948. [Link]

Peters-Lidard, C. D., E. Blackburn, X. Liang, and E. F. Wood, 1998: The effect of soil thermal conductivity parameterization on surface energy fluxes and temperatures. J.Atmos. Sci., 55, 1209-1224, doi: 10.1175/15200469(1998)055<1209:TEOSTC>2.0.CO;2. [Link]

Radell, D. B. and C. M. Rowe, 2008: An observational analysis and evaluation of land surface model accuracy in the Nebraska Sand Hills. J. Hydrometeorol., 9, 601621, doi: 10.1175/2007JHM913.1. [Link]

Rodell, M., P. R. Houser, A. A. Berg, and J. S. Famiglietti, 2005: Evaluation of 10 methods for initializing a Land Surface Model. J. Hydrometeorol., 6, 146-155, doi: 10.1175/JHM414.1. [Link]

Schaake, J. C., V. I. Koren, Q. Y. Duan, K. Mitchell, and F.
Chen, 1996: Simple water balance model for estimating runoff at different spatial and temporal scales. J. Geophys. Res., 101, 7461-7475, doi: 10.1029/95JD02892. [Link]

Sridhar, V., R. L. Elliott, and F. Chen, 2003: Scaling effects on modeled surface energy-balance components using the NOAH-OSU land surface model. J. Hydrol., 280, 105-123, doi: 10.1016/S0022-1694(03)00220-8. [Link]

Stöckli, R., D. M. Lawrence, G. Y. Niu, K. W. Oleson, P. E. Thornton, Z. L. Yang, G. B. Bonan, A. S. Denning, and S. W. Running, 2008: Use of FLUXNET in the Community Land Model development. J. Geophys. Res., 113, G01025, doi: 10.1029/2007JG000562. [Link]

Twine, T. E., W. P. Kustas, J. M. Norman, D. R. Cook, P. R. Houser, T. P. Meyers, J. H. Prueger, P. J. Starks, and M. L. Wesely, 2000: Correcting eddy-covariance flux underestimates over a grassland. Agric. For. Meteorol., 103, 279-300, doi: 10.1016/S0168-1923(00)00123-4. [Link]

Van der Meulen, M. W. J. and W. Klaassen, 1996: Soil heat flux measurements in an open forest. Phys. Chem. Earth, 21, 101-105, doi: 10.1016/S0079-1946(97)85568-1. [Link]

Van der Velde, R., Z. Su, M. Ek, M. Rodell, and Y. Ma, 2009: Influence of thermodynamic soil and vegetation parameterizations on the simulation of soil temperature states and surface fluxes by the Noah LSM over a Tibetan plateau site. Hydrol. Earth Syst. Sci., 13, 759777, doi: 10.5194/hess-13-759-2009. [Link]

Verseghy, D. L., N. A. McFarlane, and M. Lazare, 1993: Class-A Canadian land surface scheme for GCMs, II. Vegetation model and coupled runs. Int. J. Climatol., 13, 347-370, doi: 10.1002/joc.3370130402. [Link]

Whitfield, B., J. M. Jacobs, and J. Judge, 2006: Intercomparison study of the land surface process model and the common land model for a Prairie Wetland in Florida. J. Hydrometeorol., 7, 1247-1258, doi: 10.1175/ JHM547.1. [Link]

Wilson, M. F., A. Henderson-Sellers, R. E. Dickinson, and P. J. Kennedy, 1987: Sensitivity of the biosphereatmosphere transfer scheme (BATS) to the inclusion of variable soil characteristics. J. Clim. Appl. Meteorol., 26, 341-362, doi: 10.1175/1520-0450(1987)026<0341:SOTBTS>2.0.CO;2. [Link]

Yang, K., T. Koike, H. Ishikawa, J. Kim, X. Li, H. Liu, S. Liu, Y. Ma, and J. Wang, 2008: Turbulent flux transfer over bare-soil surfaces: Characteristics and parameterization. J. Appl. Meteorol. Climatol., 47, 276-290, doi: 10.1175/2007JAMC1547.1. [Link]

Yang, K., Y. Y.Chen, and J. Qin, 2009: Some practical notes on the land surface modeling in the Tibetan Plateau. Hydrol. Earth Syst. Sci., 13, 687-701, doi: 10.5194/ hess-13-687-2009. [Link] 
Yi, J., M. M. Kim, J. H. Kim, U. Ji, S. M. Ha, and S. Noh, 2010: Cheongmicheon representative basin. IHP Annual Report, 1-207.

Zeng, X. M., M. Zhao, B. K. Su, J. P. Tang, Y. Q. Zheng, Y. J. Zhang, and J. Chen, 2002: The effects of landsurface heterogeneities on regionalclimate: A sensitivity study. Meteorol. Atmos. Phys., 81, 67-83, doi: 10.1007/s007030200031. [Link]

Zilitinkevich, S., 1995: Non-local turbulent transport pollu- tion dispersion aspects of coherent structure of convective flows. In: Power, H., N. Moussiopoulos, and C. A. Brebbia (Eds.), Air Pollution Theory and Simulation, Air Pollution III, Vol. 1, Computational Mechanics Publications, Southampton, Boston, 53-60, doi: 10013/ epic.14048. [Link]

Zobler, L., 1986: A world soil file for global climate modeling. NASA Technical Memorandum 87802, New York. 